Marquette University

e-Publications@Marquette

Theology Faculty Research and Publications

Theology, Department of

$1-1-2007$

\title{
Murray: Faithful to Tradition in Context
}

Thomas Hughson

Marquette University, thomas.hughson@marquette.edu

Published version. "Murray: Faithful to Tradition in Context," in Finding God in All Things:

Celebrating Bernard Lonergan, John Courtney Murray, and Karl Rahner. Eds. Mark Bosco and David

Stagaman. New York: Fordham University Press 2007: 109-121. Publisher link. (C) 2007 Fordham University Press. Used with permission. 


\section{Murray: Faithful to TRADITION IN CONTEXT}

Thomas Hughson, S.J.

Catholics and other Christians most likely know John Courtney Murray as a protagonist in the production of the Declaration on Religious Freedom at the Second Vatican Council, published almost forty years ago. Its significance for the public life of Catholicism in religiously pluralist societies remains hard to overestimate. Social ethics, fundamental theology, practical theology, public theology, and communications are theological specialties that also have found substance in his writings.

Murray's thought on the twin topics that preoccupied so much of his reflection, Church-state relations and religious liberty, might seem defined by ties to his native land, the United States, and its charter documents to which he appealed, the Declaration of Independence, the Constitution, and the Bill of Rights. Still, the Catholic breadth of his vision is indicated by his study at the Gregorian University in Rome in the late 1930s while a young Jesuit, his academic sojourn in Germany, his dissertation on Matthias Scheeben's doctrine on faith in 1937, his continual reading of history, his attention to World War II and international affairs, his participation in post-World War II assistance to German reconstruction, his career-long interest in ecumenical and interreligious cooperation for the social common good, and his awareness of limits and defects in the culture of the United States. 
In the 1940s and into the 1950s some public Protestant doubt circulated on why and how deeply their Catholic fellow citizens endorsed what many regarded as a signal novelty and essential institution in the democratic structures of the United States-the First Amendment guarantee of free exercise and of the nonestablishment of religion. No doubts accompanied the Protestant observation that Catholics in practice supported nonestablishment and religious freedom. The question remained, was that practice principled? Or was it an expedient adjustment to national facts Catholics wished were otherwise, and which they might seek to change if they became numerous enough? Might Catholics be harboring reservations about the First Amendment clauses out of a deeper preference for an established Catholicism that papal teaching recommended as best? This was a question about Catholic thought, principle, and theory, not about practice. It was an impertinent question for families whose children had perished in military service under an oath to uphold the Constitution, but it needed an answer, and an answer in the realm of theory.

In response, starting in the mid-1940s, Murray launched an almost career-long inquiry into religious freedom and Church-state relations. The two topics are indissociable. Religious freedom in any society flourishes or does not according to the political organization of society; the state possesses a monopoly on legitimate use of coercive force in society, and the government exercises it. Religious freedom depends for protection, or suffers abuse, depending on the manner and scope of that governmental exercise of power.

Unfortunately, Catholics in the United States were not lacking a few writers who championed the thesis/hypothesis theory propounded as Catholic doctrine by, among others, Vatican Secretary of the Holy Office Alfredo Cardinal Ottaviani. His view lifted up national establishment of the Catholic Church as the ideal or thesis, and relegated anything else, such as the United States arrangement, to the inferior status of being merely a hypothesis.

By the time Pope John XXIII convoked Vatican II, Murray had become the foremost American Catholic theorist on religious liberty. Murray had entered into controversy in national public life in defense of government aid to Catholic schools as well as by arguing for recovery of a "public philosophy" of natural law truths and values. Before the 1960 presidential election, the Kennedy campaign staff consulted 
him on Church-state relations prior to a famous speech Kennedy delivered to ministers in Houston, Texas, which was intended to help set aside fears that a Catholic in the White House would mean a pope telephoning instructions to guide presidential decisions. A short time after Kennedy's victory, on December 12, 1960, Time magazine featured Murray on its cover.

At Vatican II, Murray was appointed "first scribe" in the commission charged with producing a text on religious liberty. This gave him an important role in shaping the document without his being the single architect. The final document promulgated on December 7, 1965, above the signatures of Paul VI and the assembled bishops, had undergone significant change since its inception. In the commission Murray had steadily argued through five drafts that religious liberty was best understood as primarily a political and legal reality that owed its existence to modern consciousness and institutions, not directly to Church initiatives. Affirming religious liberty by declaring official Catholic approval of an already familiar idea, practice, and set of institutions was a belated aggiornamento, not a groundbreaking development. Modesty, even a little chagrin not triumphalism, was appropriate in view of post-Tridentine Church-state relationships in the area of religious liberty.

Murray had long held that prior centuries, during which the gospel exercised a leavening influence in western political self-understandings and practices, provided a basis for a modern consciousness of human dignity and the legal institutions designed to protect its realization in practice. Well versed in the historical record of protracted conflicts between Church authorities and political leaders from Constantine on, he also pointed out repeated assertions of papal independence in judgment and ministry. The mustard seed of post-Constantinian papal defense of the libertas ecclesiae (freedom of the Church) became a tree of faith sheltering both civil society and the eventual emergence of demands for individual freedom in religion.

That tree had sometimes been shaken, as with Innocent III, who crowded out political authority on the premise that all temporal as well as spiritual power passed from Jesus to Peter to popes, and on that foundation he believed that popes rightly seated and unseated emperors and kings. The ancient dualism of Pope Gelasius had not been forgotten, however. In A.D. 494, Gelasius wrote to Emperor Anastasios I: "Two there are, august Emperor, but which this world is ruled on the title of 
original and sovereign right - the consecrated authority of the priesthood and the royal power." Recalling this vision was Leo XIII's achievement and to develop it was Murray's continuing task. This dualism was, Murray agreed; the major impact of Christianity on political life, and applied Jesus' God/Caesar difference.

On the basis of this diarchy, Murray recognized the legitimacy of royal claims to independence from ecclesiastical jurisdiction in political judgment and action. His views increasingly followed Thomas Aquinas and John of Paris on the natural law, temporal purposes of the political structures in any society. He came to disagree with Robert Bellarmine's proposal that in religious emergencies, not as a regular matter, a pope could temporarily exercise authority over a political area for a good spiritual end. This limit purified the exercise of apostolic jurisdiction without infringing on the duty to teach the gospel. Contrarily, even if requested by a pope or bishop on behalf of a society's spiritual welfare, any governmental repression of heresies precisely as religious doctrines and practices overstepped the bounds of political authority, though a state always had a duty toward public order, safety, and civil morality.

Murray assimilated the nineteenth-century papacy's critique of the supremacy of the individual reason (continental liberalism), especially when writ large as a nation-state's supreme authority in all zones of social existence (totalitarianism). Consequently he contrasted the Anglo-American tradition of constitutional government (which he considered unknown to Leo XIII), including the United States constitutional provisions of nonestablishment and religious liberty, to continental state absolutism (which Leo knew from the French Revolution and its aftermath). He argued that medieval recognition that the consent of the governed belonged to the legitimacy of political authority passed to the founding of the United States, not through the Catholic nations of continental Europe, but through England, where the Magna Carta in 1215 initiated a long train of curtailments to monarchical power. The concept of a divine right, absolute monarch in Europe was a bad idea with demonstrably negative consequences. Governance under a constitution was' a much better political idea because governmental exercise of power was submitted to the rule of known public law. It was more congruent with Gelasian dualism than was, for example, l'état c'est moi.

Murray focused to a surprising extent on what today would be called political culture and civil society, not solely on laws, structures, and the 
technical procedures of democracy. In fact, the theoretical and operational priority of society over the state was both a cardinal emphasis in Catholic social teaching and was the hallmark of resistance to totalitarianism of the right or left. Simply put, the state and government existed for the good of society and the people, not the other way around. States and governments, however, have a momentum of their own that tends to reverse this. Nor do I think Murray would have expected that a democracy would spring up like a mushroom, in Russia for example, if only a stone of oppressive state fascism were removed. A functional civil society is a more substantial prerequisite for democracy than a warehouse filled with voting booths.

Moreover, Murray's understanding of civil society and political culture was thoroughly historical. He stated that, "the Bill of Rights is not a piece of eighteenth-century rationalist theory; it is far more the product of Christian history." Behind it lay not John Locke's books so much as a lengthy British progress toward the commonly accepted "rights of an Englishman." And underpinning that progress were people who had learned their human dignity "in the school of Christian faith," and a political culture that developed and applied the principle of the consent of the governed under a rule of law.

In that light, free exercise of religion is a public, social condition dependent on a state respecting the limits of its authority, which is to say that this authority is nonexistent in regard to religion. Historical arrival at this position depends on a prior affirmation of human dignity and on some manner of religion-state dualism. On the dualist premise, political governance for Christians - and perhaps unlike Church or religious authority in a non-Christian religion-has no authority from the Creator to define or decide religious belief, practice, or institutional existence, though it must see to public safety, order, and morality. In the founding of the United States, for example, it was not the religion clauses in the First Amendment of the Bill of Rights that anchored protection for liberty of religion. The clauses simply made explicit the civil liberties of individuals in a limited state with enumerated powers. Authority to establish religion or prevent its free exercise was not on the list of powers. The Constitution already, before the Bill of Rights, had eliminated establishment and assured free exercise.

Keeping in mind the formative English history behind the Constitution leads us to a realization that some form of widespread education accessible to a people, rather than simply elections, is the first step in 
forming a democratic state. In trying to support democracies around the world, Western powers may look too much to elections, written laws, and a willingness to compromise, while scanting the essential roles of education, political culture, and formation in human dignity. Likewise, human rights monitors attending to freedom of religion hopefully attend carefully to a people's whole everyday way of life and their culture rather than only to written statutes. De facto conditions, not simply de jure documentation, need to weigh heavily in any plans to form or support democracy. Murray emphasized that the founding of the United States was not according to a preconceived, doctrinaire plan.

An alternative perspective argued within the Vatican II preparatory commission focused on individual human rights. This view of the human and civil right to religious liberty revolves around individual human rights, and around the freedom of individual conscience, or in the Catholic version, the dignity of the human person that grounds the "rights of man." Once the conciliar text embraced the principle, it had to balance it with a teaching that the innate obligation to the truth, not arbitrary personal preference, formed personal freedom of conscience and religion. Murray fell ill and was hospitalized during the final rewrite of the document. So in the final text the "individual" argument assumed a larger role than it would have if Murray had been active. He saluted its publication with two cheers, not three.

Murray upheld, of course, freedom of conscience and the dignity of the person as essential to civil society. Christian freedom was something more. It had a communal aspect, and sprang from the new human situation due to Christ, the gospel, and the Holy Spirit. It flourished insofar as Christians opened themselves to the leading of God, and issued in zeal for the gospel. It also pertained to life inside the Church. After the Council, Murray commented that Vatican II moved the Church out of a post-Tridentine configuration in regard to Christian freedom. Four centuries of understandable pastoral reaction to rejections of ecclesiastical authority, first by the Reformation and then by the Enlightenment, amounted to hypertrophy of the principle of authority, with a correlative atrophy of the principle of freedom in the Church. Conciliar renewal reaffirmed Christian freedom.

But in civil society Murray thought protection for free exercise of religion came first and foremost from circumscribing state authority within due bounds, not from asserting individual freedoms. The text voted by the bishops and signed by Pope Paul VI, nonetheless, offers 
more common ground with Protestant understandings of religious freedom, and so better serves the ecumenical goal of the Council. Murray's approach remains a sign of Catholic understanding that social and political dimensions are internal to personal liberty, not added on from outside to a purely individual or private reality.

\section{Two Dramas}

Was the contest between alternative views of religious liberty within the drafting commission the central drama of Murray's theological career? Probably not. True, all his previous research and reflection indeed came into play - the stakes were high, the differences real, the arguments sharp. But the commission was, after all, collaborative if strenuous. Any conflict was subordinate to a common purpose. There were, however, two conflicts in Murray's life as a theologian that do qualify as major dramas. Both arose from the fact that Catholicism in the United States has had a quality of originality that American Protestants and European Catholics alike had a hard time locating. Drama involves a main character contending with inescapable tensions, an apex of conflict, and a denouement.

The Protestant/Catholic drama in the United States was a set of tensions between an immigrant Catholicism gaining its place after World War II and a culturally regnant Protestant ethos gradually coming to terms with religious pluralism. Many Protestants still saw Catholics in the United States as the local presence of European Catholicism. They had read Leo XIII's fulminations against religious liberty and Churchstate separation, had observed Vatican policy in making Church-state concordats, and saw how Spain was taken by Rome to exemplify the establishment wanted by the Church. Murray's extensive writing on Church-state matters was a prolonged demonstration that the Church's actions, policies, and theories in Church-state relations had historically contingent elements. Some in the Church, highly placed at that, mistook post-Reformation, post-wars of religion alliances with confessional states as an immediate consequence of Catholic faith, treating Spain as if universally normative. Catholicism in the United States had never wanted establishment. Doubts about American Catholics were unfounded. His interest was in citizens of all religions cooperating for the common good and for the intellectual empowerment of Catholics to 
pick up their share of active citizenship in a religiously pluralist democracy.

Murray's best-known book, the preconciliar We Hold These Truths: Catholic Reflections on the American Proposition (1960) capped a theoretical explanation of how and why Catholics consented to the American experiment in full fidelity to Catholic principles. ${ }^{1}$ At the basis was a theory of Church-state relations summed up in four principles. The first principle was the irreducible difference in origin, activity, and end of Church and state. The second principle was the effective spiritual primacy of the Church and faith in relations with the political order. The third principle was the integrity of the political order and its independence from ecclesiastical jurisdiction. The fourth principle affirmed the immanent finality of Church and state to some manner of harmony for the sake of those who belong to both simultaneously. Much of Murray's work concentrated on the third principle, which he took to be a valid modern differentiation between sacred and secular. He understood this to be true to Catholic tradition on Church and state and more particularly to Leo XIII's development of it.

The election of John F. Kennedy in 1960 seemed to have settled in practice what Murray had demonstrated in theory. It drew the Protestant/Catholic drama in the United States to its last act. The Catholic faith, the outcome of the election showed, did not preclude a Catholic citizen from becoming president. Kennedy's executive prowess showed it did not entail submission to the authority of the pope as temporal ruler, as if American Catholics were subjects in the former papal states. Finally, though, it was the 1965 Declaration on Ecumenism that removed the underlying premise for the post-Reformation, Protestant/ Catholic drama in every nation, at least from the Catholic side. The older premise, that Protestant and Catholic were first of all antagonists over Christian truth, became awareness that what we have in common is greater than what divides us. The ecumenical movement, among Protestants who accept ecumenism, the Orthodox, and Catholics, has resolved the Protestant/Catholic drama in which Murray played a part. Subsequently, the 2004 debate over another Catholic citizen's electoral campaign in the United States advises that the Protestant/Catholic drama has ceded to "culture wars" within the Catholic Church, as well as among Protestant and Orthodox Americans. Murray's theory of civil dialogue has much to offer this condition too. 
There was a second drama in Murray's theological life. Another set of tensions sprang up between Murray and the dominant school of thought on Church-state relations that had representatives in Rome and in the United States. This was a tradition/modernity conflict. It played out through conflict, resolution, and denouement in Murray's relations with the Vatican. His book We Hold These Truths followed painful tension with Alfredo Cardinal Ottaviani, Vatican Secretary of the Holy Office (now the Congregation for the Doctrine of the Faith), who published and acted on a Church-state theory of tolerant establishment where a predominantly Catholic population made this feasible, as it did in Spain. The tragic climax was the silencing of Murray by his religious superiors on the Church-state topic in 1954. Behind this lay a background of European Catholic difficulty in grasping that Catholics in the United States, a mission country, were actually Catholic but inculturated in a different way. Many in Catholic Europe had seen the United States as a Protestant nation, American Catholics as quasi-Protestant, and the pairing of religious liberty with nonestablishment as contrary to Catholic tradition.

In response, Murray pointed to the historical contingency of the post-Reformation confessional state in order to remove its ostensible status as an arrangement that Catholic doctrines demanded as a necessary consequence of their truth. What the state owed the Church was not establishment but protection of its citizens' religious liberty, so the Church could flourish from its own native energies apart from state coercion. Murray distinguished Anglo-American constitutionalism from what Leo XIII had learned about and condemned in democracy carried by the French Revolution and its aftermath.

A lesser-known book by Murray, The Problem of Religious Freedom, made the case at Vatican II that conciliar development beyond Leo's gravamen against religious liberty and Church-state separation was possible because in historical context Leo inveighed only against certain kinds of nineteenth-century, continental instantiations of these, not all possible versions. ${ }^{2}$ That Murray's view on this carried the day, that he was a peritus at Vatican II in the first place, that he had a significant hand in drafting the Decree on Religious Liberty, and that he received a special blessing from Paul VI, resolved the conflict with Ottaviani. Notable is the fact that Leo XIII, Catholic social teaching after him, Murray, and Vatican II, all have taken their bearing on political 
life from Aquinas rather than Augustine's City of God. This poses a challenge to neo-Augustinian social theologies.

\section{Concluding Reflection}

In a monarchy or nondemocratic state, relations between Church and state occur insofar as legitimate authorities representing each "perfect society" meet and conduct business together. Church and state convened in meetings, or in relationships carried out according to formal, legal arrangements between popes and emperors, popes and kings, bishops and princes, clergy and magistrates. Leo brought forward recognition that such relationships were not for the sake of authorities themselves, or only for the dignity of the offices they occupied, but above all for the sake of peoples beneath them. The civis idem et christianus, the citizen (or subject) who was both under state and Church authority, had duties to fulfill in both societies. If Church and state authorities were at odds to the extent that they commanded opposite acts, the effect was to introduce division into the consciousness of Christians who owed obedience to both. This interior conflict was contrary to the peaceful conscience that the New Testament commended as the condition in which followers of Christ could conduct their lives of faith under God's supreme authority in Christ, visibly represented by those succeeding the apostles, while also obeying legitimate political authority.

Pius XII took this a step further by identifying the person as the source, agent, and end of all societal processes. This meant, and it was carried through most fully in a democratic state, that Church-state relations were not only for the sake of the people who dutifully received decisions made above their heads and then harmonized them. Rather, the relations passed through the people. Ordinary people were involved in and were agents in those relations. Murray clarified it as follows: In a democracy the first officer is the citizen, not the elected or appointed official. The citizen is the state's representative in relating to the Church. Whom does that citizen encounter as representative of the Church? That same person himself or herself as baptized believer, the one person who is both believer and citizen is the meeting point.

A nonestablishment regime does not recognize the religious authority of a bishop, pope, or any Church authority as having jurisdiction 
over any part of the political order. So the conduct of Church-state relations devolves to the believer/citizen. In them, in their consciences, Church and state meet and seek a harmonious relationship. Conscience becomes the meeting hall. The Church represented by the person-asbeliever and the state represented by the person-as-citizen are in continual, usually quiet session.

It follows, I suggest, that ecclesiastical authority cannot intervene in a Catholic citizen's conscience by laying upon it a command to perform or act on a particular political judgment. That prudential judgment, rather, is an irreplaceable function of the believer's own conscience, which also has the obligation to form itself according to Catholic faith and morality. To be sure, apostolic authority has every right to fulfill a duty to preach and teach the gospel in its implications for public life and for the political order of society. This might lead to making public judgments on the immorality of specific public policies or their administration. That is one thing; it is another thing to try to exercise ecclesiastical jurisdiction over the person's politically prudential judgment. That is, to attempt direct exercise of ecclesiastical authority over something political in nature, namely, the proper act of an informed citizen. That turns the ecclesiastical act into an act of a political nature. No less than commanding a government official to repress a heresy, this violates the hard-won differentiation between the temporal and the spiritual and runs against the spiritual mission of the Church. Equally a state, its government and officials have no basis and no authority to command that an act of religious nature be performed by citizens, whether the act be internal like personal prayer or belief that God has chosen one's nation for the mission of spreading democracy, or external-like attendance at worship or professing that the unborn are nonhuman.

Leo XIII and Murray's fourth principle, of a finality in Church and state to a mode of harmony that permits peaceful consciences, does not mean peace at any price. Nor does it imply that believers are to treat their faith and their political views as if on par. Nothing suggests anything other than that faith and discipleship are an all-encompassing principle of interpretation, not to be subordinated to political convictions. Harmony presupposes and includes the exercise of political prudence and practical reason. So harmony does not result from what some seem to think is the proper path-a unilateral, rapidly executed jump 
from faith to prudential decisions on specific laws or policies without an intervening deliberation. To move from a biblical passage, a traditional theme, a papal teaching, a personal spirituality to a political decision without passing through analysis, discussion, reading, and reflection precisely on the political level, is to bypass the virtue of prudence, rather than to stand for the demands of faith. This would be practical fideism.

Consciences, not legislatures or Vatican halls, are host to the most intimate, durable, and influential Church/state relationships. This was how Murray envisioned the dignity and role of conscience in regard to Church and the political order, not so much as a demand for freedom, but as the arena wherein the gospel meets and guides political life.

Consequently, he placed a good deal of value in Church authorities exercising the power of the Church to influence society indirectly by helping the faithful to form their consciences in light of Catholic faith and morality. Direct influence by means of prelates inserting their influence into chambers of law above the heads of believer-citizens, or seeking to steer democratic processes by commanding a political act, runs contrary to the Church/state difference. Strictly speaking, though Murray did not draw this conclusion explicitly, it seems that pope, bishop, or clergy would have no basis for commanding believers to vote this way or that, to take this or that political action. However, the indirect influence of apostolic authority on society by educative formation of consciences is an obligation. Catholics have a correlative duty to learn and to act on the implications of their faith for the temporal order of society, including its morality. Murray insisted, and took his cue from Pope Pius XII on this, that the moral order and legal orders were distinct, that the passage from the moral order to the legal order depended greatly on historical, cultural, social context and conditions; that social peace was of such value that in a pluralist society, it could demand restraint from seeking a direct passage from the moral order to the legal order in a given matter.

It has turned out that practical and theoretical tensions around the second and fourth principles in Catholic Church-state theory have outlived Murray, making him a character in a plot without a climax, resolution, and denouement. He participated in the larger historical drama arising from tensions between Catholicism and American political life. His basic position is now less taken for granted as a direction for future development, unfortunately. Problems attendant upon some modes of 
episcopal presence in American public life would have been averted or ameliorated were Murray better known to today's prelates. Critiques that reject rather than criticize and develop his contribution seem to have lost confidence in the potential for social change in democracy, or to have reverted to an Augustinian political theology in the name of authentic Catholicity. Whatever the cause, the fact is that Murray's contribution has not connected with many bishops. Critical appropriation and development of his Church-state thought is needed.

In light of a theology of religious pluralism today, it can be added that in some analogous way the Church/state difference pertains to and supports the spiritual integrity of any religion as well as affirms its independence from jurisdiction of any political authority. 